\author{
Anna Misztal \\ University of Lodz, Faculty of Economics and Sociology \\ e-mail: anna.misztal@uni.lodz.pl \\ ORCID: 0000-0002-7455-5290
}

\title{
ASSESSING THE IMPACT OF THE FINANCIAL CONDITION ON THE COMPONENTS OF SUSTAINABLE DEVELOPMENT OF TRANSPORT ENTERPRISES IN POLAND IN 2008-2019
}

DOI: $10.15611 / \mathrm{pn} .2021 .1 .07$

JEL Classification: C13, L32, Q01

\section{(C) 2021 Anna Misztal}

This work is licensed under the Creative Commons Attribution-ShareAlike 4.0 International License. To view a copy of this license, visit http://creativecommons.org/licenses/by-sa/4.0/

Quote as: Misztal,A. (2021). Assessing the impact of the financial condition on the components of sustainable development of transport enterprises in Poland in 2008-2019. Prace Naukowe Uniwersytetu Ekonomicznego we Wroctawiu, 65(1).

\begin{abstract}
The sustainable development of an enterprise includes the implementation of the economic, social, and environmental goals. In business practice, this means taking actions to maximize profits while implementing social and ecological tasks. The article's primary goal is to assess the impact of the financial condition on the components of sustainable development of transport companies in Poland in 2008-2019. A company's sustainable development is understood here as achieving the intended economic, social, and environmental results. The primary method used in the study is the Ordinary Least Squares (OLS) method, which allowed for the estimation of three equations in which the endogenous variables are economic $\left(\mathrm{E}_{\mathrm{D}}\right)$, social $\left(\mathrm{S}_{\mathrm{D}}\right)$ and environmental development $\left(\mathrm{Env}_{\mathrm{D}}\right)$. According to the estimation results, the individual components are interdependent. The financial condition $\left(\mathrm{F}_{\mathrm{C}}\right)$ for the current period and the previous one impact on economic and social development, while environmental development depends on its financial situation.
\end{abstract}

Keywords: financial condition, sustainable development, transport enterprises, the OLS model.

\section{Introduction}

Progressive economic development and globalization have contributed to an increase in the scale of environmental pollution. Thus it became necessary to create rules and standards for nature protection and to take decisive measures to counteract climate 
change. The increase in public awareness and the development of technologies and ecological innovations have contributed to creating sustainable growth.

Sustainable development is a socio-economic development based on environmental protection. The goal is to preserve nature's resources for future generations. Implementing the concept requires involving all sides of social and economic life, including countries, international institutions, and enterprises. An enterprise's sustainable development means achieving a specific balance in the economic, social, and environmental dimensions. In business practice, this requires foregoing part of the profits to benefit investments in human capital, employee health protection, and the natural environment.

This paper aims to assess the impact of the financial condition $(\mathrm{Fc})$ on the components of sustainable development of transport enterprises in Poland in 2008-2019. The central research hypothesis is as follows: "The financial condition has a statistically significant impact on the economic, social and environmental development of transport enterprises in Poland in 2008-2019”. To verify the hypothesis, the author used the Ordinary Least Squares (OLS) method. The research covered the transport enterprises sector due to their high emission of harmful substances and its vital role in developing other economic sectors. The data used in the research come from the GUS.

\section{Sustainable development of enterprises - selected theoretical problems}

An enterprise's sustainable development means implementing economic, social, and environmental goals (Ikram, Zhou, Shah, \& Liu, 2019, pp. 628-641; Mao, Li, Pei, \& Xu, 2018; Misztal \& Kowalska, 2020, pp. 160-173; Witek-Crabb, 2005). Sustainable development is a holistic concept that applies to the functioning of all economic entities (Kapecki, 2020; Karagülle, 2012, pp. 456-460; Piontek, 2002; Schroeder \& Robinson, 2010; Trojanowski, 2015; Yemelyanov et al., 2020). Achieving sustainability goals requires commitment from owners and employees alike.

In business practice, this is the sum of choices and the partial shift from current economic profits, in favour of activities supporting social and ecological development (Adamkiewicz-Drwiłło \& Kruk, 2010, pp. 16-24; Czyż, 2000; Leśniewski, 2017, pp. 17-34; Oželiené, 2017). Maintaining appropriate relations between strictly economic categories such as economic value, added value or net profit, and social and ecological investments, is crucial in building a competitive advantage (Kang \& Na, 2020; Koszel \& Weinert, 2013, p. 155; Ricart, Rodríguez, \& Sánchez, 2002; Srivastava, Franklin, \& Martinette, 2013, pp. 47-60).

The theory of sustainable development is related to the view of corporate social responsibility (CSR), in fact they are similar and complementary. Some researchers 
emphasize that CSR is a form of the corporate concept of sustainable development (Behringer \& Szegedi, 2016, pp. 10-25; Bembenek, 2015; Carroll, 2015, pp. 87-96).

Sustainable development requires applying principles and rules aimed at the practical and rational use of natural resources and reducing harmful substance emissions (McIntyre, Ivanaj, \& Ivanaj, 2009). Limiting the natural environment's negative impact requires undertaking ecological investments, implementing eco-innovations and environmentally friendly technologies (Drljača, 2012; Sarkar, 2013, pp. 171-224; Yurdakul \& Kazan, 2020). In addition to ecological initiatives, it is also necessary to improve and protect employees' health and support for local communities (Kokić, Mišić, Radojković, \& Prlinčević, 2016).

An essential element of sustainable development is making decisions considering their shared value (Porter \& Kramer, 2007). This means the capability of an enterprise to last over time, which requires achieving a satisfactory level of productivity and financial performance, and also beneficial social and environmental effects (Giovannoni \& Fabietti, 2013). The sustainable development of an enterprise consists of three components (pillars) (Misztal, 2019):

- economic development, which can be equated with an increase in assets, an increase in the company's value or net profit,

- social development, which is manifested in the improvement of working conditions, taking actions for the development of human capital, safety and health protection of employees, support for the development of local communities,

- ecological development, the effect of activities should be to reduce the emission of harmful substances.

Sustainable development is the sum of the economic, social, and environmental effects. The components of sustainable development are very often not correlated with each other. Moreover, very often, economic growth occurs at the expense of social and environmental action (Pieloch, Misztal, \& Kowalska, 2020).

Sustainable development requires a change in the approach to management, introducing environmental management and focusing on providing value-added to customers (Adamczyk, 2001; Firlej, 2005, pp. 263-269).

Sustainable development determinants can be divided into two groups (Moya-Clemente, 2020; Yeasmin, 2016, pp. 129-159):

- exogenous, related to the environment, including the macroeconomic situation, economic situation, social awareness, legal regulations,

- endogenous, corresponding to the company's financial condition, sector of activity, management approach, and owners and employees' ecological attitude. The financial condition influences sustainable development, although the analysis in this area is insufficient and requires further research. The financial condition (financial and property situation) is the basis for assessing an enterprise's competitive position in the market (Janas, 2019, pp. 176-194). An excellent financial condition is 
achieved when the company has financial liquidity, high profitability, low level of indebtedness, and operational efficiency, which is of crucial importance in terms of its investment ability (Masztalerz, 2019, pp. 99-118; Skoczylas \& Waśniewski, 2014, pp. 243-252). The relationship between financial liquidity and sustainability is the subject of research, which emphasizes the fact that financial liquidity is essential for creditworthiness (Gorczyńska, 2013, pp. 99-110; Lagoarde-Segot, 2020); on the other hand, sustainable development can increase profitability in the long run (Seelos \& Mair, 2005; Osmanagić Bedenik, 2018).

The selection of transport enterprises for the research sample is related to their significant negative impact on the natural environment. Moreover, transport enterprises play a vital role in the development of other economic sectors, currently producing 5.8\% of Poland's GDP (the share of the transport sector in generating GDP in Poland is much higher than in most European countries), being the third most crucial branch of the economy after industry and trade (Comporek, Misztal, \& Kowalska, 2021).

\section{Methodology of the research}

The research aims to assess the impact of the financial condition $(\mathrm{Fc})$ on the components of sustainable development of transport enterprises in Poland in 2008-2019. The study covers the period of economic slowdown and the slow recovery from it. This research focuses on transport enterprises due to their crucial role in developing other sectors of the economy. It is also not without significance that these companies contribute to the natural environment's degradation due to harmful substances. The central research hypothesis $(\mathrm{H})$ is as follows: "The financial condition has a statistically significant impact on the economic $\left(\mathrm{E}_{\mathrm{D}}\right)$, social $\left(\mathrm{S}_{\mathrm{D}}\right)$ and environmental development $\left(\operatorname{Env}_{\mathrm{D}}\right)$ of transport enterprises in Poland in 2008-2019". The justification for such a research hypothesis is that the property condition (the enterprise's financial and property situation) significantly influences enterprises' investment decisions.

The sub-hypotheses are as follows:

- $\mathrm{H}_{1}$ : "In the period 2008-2019, there was a growing trend of economic, social and environmental development indicators".

Justification: slow recovery from the economic crisis, economic recovery, development of transport services, improvement of consumer mood,

- $\mathrm{H}_{2}$ : "In 2008-2019, the financial condition of transport enterprises in Poland improved".

Justification: good economic situation, investments, credit availability,

- $\mathrm{H}_{3}$ : "Economic development was statistically important for the social and environmental development of transport enterprises in Poland in 2008-2019" 
Justification: enterprises are primarily interested in economic issues (profit maximization, enterprise value) and only then, having stable economic foundations, implement social and environmental investments,

- $\mathrm{H}_{4}$ : "The components of the sustainable development of transport enterprises depend on each other and the financial condition".

Justification: Economic development as the foundation of social and environmental development.

The Pearson Correlation Coefficient and the Ordinary Least Squares (OLS) method are one of the most common methods of estimating linear models to verify the research hypothesis. This research consists of three stages.

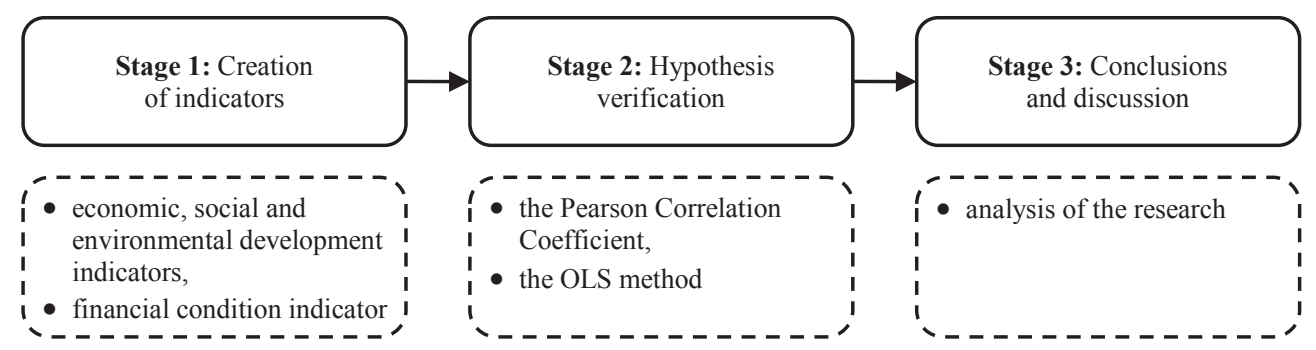

Fig. 1. Stages of the research

Source: own study.

In the first step the author calculated the sustainable development indicator (SI), which consists of three components: economic $\left(\mathrm{E}_{\mathrm{D}}\right)$, social $\left(\mathrm{S}_{\mathrm{D}}\right)$ and environmental $\left(\right.$ Env $\left._{\mathrm{D}}\right)$, and the financial condition indicator $\left(\mathrm{F}_{\mathrm{C}}\right)$ using the following formulas (Szanduła, 2014):

- for the stimulants:

$$
z_{i j}=\frac{x_{i j}-\min _{i}\left\{x_{i j}\right\}}{\max _{i}\left\{x_{i j}\right\}-\min _{i}\left\{x_{i j}\right\}}, z_{i j} \in[0 ; 1] ;
$$

- for the destimulants:

$$
z_{i j}=\frac{\max _{i}\left\{x_{i j}\right\}-x_{i j}}{\max _{i}\left\{x_{i j}\right\}-\min _{i}\left\{x_{i j}\right\}}, z_{i j} \in[0 ; 1] .
$$

where: $z_{i j}$ stands for the normalized value of the $j$-th variable in the $i$-th year; $x_{i j}$ is the value of the $j$-th variable in the $i$-th year; $\min _{i}\left\{x_{i j}\right\}$ is the lowest value of the $j$-th variable in the $i$-th year; $\max _{i}\left\{x_{i j}\right\}$ is the highest value of the $j$-th variable in the $i$-th year.

To calculate the indicator of sustainable development of transport enterprises (SI), the following formula was used: 


$$
S I_{i}=\frac{1}{n} \sum_{z=1}^{n} z_{i j}, \quad(i=1,2, \ldots, n)
$$

where: $S I_{i}$ stands for the indicator in the $i$-year; $n$ is the number of metrics; others as above.

\section{The diagnostic variables used in the model are presented in Table 1.}

Table 1. Diagnostic variables used in the creation of economic $\left(\mathrm{E}_{\mathrm{D}}\right)$, social $\left(\mathrm{S}_{\mathrm{D}}\right)$ and environmental $\left(\right.$ Env $\left._{\mathrm{D}}\right)$, and the financial condition indicator $\left(\mathrm{F}_{\mathrm{C}}\right)$

\begin{tabular}{|c|c|c|c|c|}
\hline Indicator & $\begin{array}{c}\text { Diagnostic } \\
\text { variable }\end{array}$ & Description of the variable & Stimulant & Destimulant \\
\hline \multirow[t]{8}{*}{$E_{D}$} & $\mathrm{x}_{1}$ & Transport enterprises - number & $\mathrm{x}$ & \\
\hline & $\mathrm{x}_{2}$ & Turnover or gross premiums [million euro] & $\mathrm{x}$ & \\
\hline & $\mathrm{x}_{3}$ & Production value [million euro] & $\mathrm{x}$ & \\
\hline & $\mathrm{x}_{4}$ & Value added at factor cost [million euro] & $\mathrm{x}$ & \\
\hline & $\mathrm{x}_{5}$ & Gross operating surplus [million euro] & $\mathrm{x}$ & \\
\hline & $\mathrm{x}_{6}$ & Total purchases of goods and services [million euro] & $\mathrm{x}$ & \\
\hline & $\mathrm{x}_{7}$ & Gross investment in tangible goods [million euro] & $\mathrm{x}$ & \\
\hline & $\mathrm{x}_{8}$ & $\begin{array}{l}\text { Investment rate (investment/value added at factors cost) } \\
\text { [percentage] }\end{array}$ & $\mathrm{x}$ & \\
\hline \multirow[t]{10}{*}{$\mathrm{S}_{\mathrm{D}}$} & $\mathrm{x}_{9}$ & Personnel costs [million euro] & & $\mathrm{x}$ \\
\hline & $\mathrm{x}_{10}$ & Wages and Salaries [million euro] & $\mathrm{x}$ & \\
\hline & $\mathrm{x}_{11}$ & Social security costs [million euro] & $\mathrm{x}$ & \\
\hline & $x_{12}$ & Employee - number & $\mathrm{x}$ & \\
\hline & $\mathrm{x}_{13}$ & Turnover per person employed [thousand euro] & $\mathrm{x}$ & \\
\hline & $\mathrm{x}_{14}$ & Apparent labour productivity [thousand euro] & $\mathrm{x}$ & \\
\hline & $\mathrm{x}_{15}$ & Gross value added per employee [thousand euro] & $\mathrm{x}$ & \\
\hline & $\mathrm{x}_{16}$ & Share of personnel costs in production - percentage & & $\mathrm{x}$ \\
\hline & $\mathrm{x}_{17}$ & Growth rate of employment [\%] & $\mathrm{x}$ & \\
\hline & $\mathrm{x}_{18}$ & Investment per person employed [thousands euro] & $\mathrm{x}$ & \\
\hline \multirow[t]{7}{*}{$\operatorname{Env}_{\mathrm{D}}$} & $\mathrm{x}_{19}$ & Carbon dioxide emission [tons] & & $\mathrm{x}$ \\
\hline & $\mathrm{x}_{20}$ & Methane emission [tons] & & $\mathrm{x}$ \\
\hline & $\mathrm{x}_{21}$ & Nitrous oxide emission [tons] & & $\mathrm{x}$ \\
\hline & $x_{22}$ & Sulphur oxides emission [tons] & & $\mathrm{x}$ \\
\hline & $\mathrm{x}_{23}$ & Carbon monoxide emission [tons] & & $\mathrm{x}$ \\
\hline & $\mathrm{x}_{24}$ & Nitrogen oxides emission [tons] & & $\mathrm{x}$ \\
\hline & $\mathrm{X}_{25}$ & Amonia emissions [tons] & & $\mathrm{x}$ \\
\hline \multirow[t]{9}{*}{$\mathrm{F}_{\mathrm{C}}$} & $x_{26}$ & Financial liquidity ratio & $\mathrm{x}$ & \\
\hline & $x_{27}$ & Return on sales (ROS) & $\mathrm{x}$ & \\
\hline & $\mathrm{x}_{28}$ & Return on assets (ROA) & $\mathrm{x}$ & \\
\hline & $\mathrm{X}_{29}$ & Return on equity (ROE) & $\mathrm{x}$ & \\
\hline & $\mathrm{x}_{30}$ & Equity ratio in financing assets & $\mathrm{x}$ & \\
\hline & $\mathrm{x}_{31}$ & Assets structure ratio & $\mathrm{x}$ & \\
\hline & $\mathrm{x}_{32}$ & Inventory/stock turnover ratio (in days) & & $\mathrm{x}$ \\
\hline & $\mathrm{x}_{33}$ & Receivables turnover ratio (in days) & & $\mathrm{x}$ \\
\hline & $\mathrm{x}_{34}$ & Debt ratio & & $\mathrm{x}$ \\
\hline
\end{tabular}

Source: own study based on (GUS, n.d.). 
In the next step the author measured the strength of a linear relationship between the indicators with the Pearson's Correlation Coefficient given by the formulas (Ahlgren, Jarneving, \& Rousseau, 2003)

$$
r_{x y}=\frac{\sum_{i=1}^{n}\left(x_{i}-\bar{x}\right)\left(y_{i}-\bar{y}\right)}{\sqrt{\sum_{i=1}^{n}\left(x_{i}-\bar{x}\right)^{2}} \sqrt{\sum_{i=1}^{n}\left(y_{i}-\bar{y}\right)^{2}}}, \quad r_{x y} \in[-1 ; 1]
$$

where: $r_{x y}$ stands for the Pearson's correlation coefficient; $n$ is the sample size; $x_{i}, y_{i}$ are the individual sample points indexed with $i ; \bar{x}, \bar{y}$ are the sample means.

Then, the structural equation model was used to assess the impact of financial condition $\left(\mathrm{F}_{\mathrm{C}}\right)$ on the economic $\left(\mathrm{E}_{\mathrm{D}}\right)$, social $\left(\mathrm{S}_{\mathrm{D}}\right)$ and environmental $\left(\operatorname{Env}_{\mathrm{D}}\right)$ development. The model is based on the formula:

$$
\left\{\begin{array}{l}
E_{D}=\text { const }+S_{D}+S_{D(t-1)}+E n v_{D t}+E n v_{D(t-1)}+F_{C t}+F_{C(t-1)}+E_{D(t-1)} \\
S_{D}=\text { const }+E_{D}+E_{D(t-1)}+E n v_{D t}+E n v_{D(t-1)}+F_{C t}+F_{C(t-1)}+S_{D(t-1)} \\
E n v_{D}=\text { const }+E_{D}+E_{D(t-1)}+S_{D}+S_{D(t-1)}+F_{C t}+F_{C(t-1)}+E n v_{D(t-1)}
\end{array}\right.
$$

The exogenous variables include: $\mathrm{F}_{\mathrm{C}}, \mathrm{F}_{\mathrm{C}(\mathrm{t}-1)}$. The analytical record presented, after conversion to the matrix record, gives a model in the form of:

$$
\left[\begin{array}{c}
E_{D t} \\
S_{D t} \\
E n v_{D t}
\end{array}\right]=\left[\begin{array}{ccccccccc}
\beta_{10} & \beta_{11} & \beta_{12} & \beta_{13} & \beta_{14} & \beta_{15} & \beta_{16} & \beta_{17} & 0 \\
\beta_{20} & 0 & \beta_{22} & \beta_{23} & \beta_{24} & \beta_{25} & \beta_{26} & \beta_{27} & \beta_{28} \\
\beta_{30} & \beta_{31} & \beta_{32} & 0 & \beta_{34} & \beta_{35} & \beta_{36} & \beta_{37} & \beta_{38}
\end{array}\right]\left[\begin{array}{c}
1 \\
S_{D t} \\
S_{D(t-1)} \\
E n v_{D t} \\
E n v_{D(t-1)} \\
F_{C t} \\
F_{C(t-1)} \\
E_{D(t-1)} \\
E_{D}
\end{array}\right]+\left[\begin{array}{c}
\varepsilon_{1 t} \\
\varepsilon_{2 t} \\
\varepsilon_{3 t}
\end{array}\right]
$$

To assess the links between the components of sustainable development of enterprises and financial condition indicator, the OLS method is used, based on the formulas:

$$
\begin{aligned}
E_{D i}=\hat{\beta}_{0}+\hat{\beta}_{1} S_{D i} & +\hat{\beta}_{2} S_{D(t-1) i}+\hat{\beta}_{3} E n v_{D t i}+\hat{\beta}_{4} E n v_{D(t-1) i}+\hat{\beta}_{5} F_{C i}+\hat{\beta}_{6} F_{C(t-1) i}+\hat{\beta}_{7} E_{D(t-1) i} \\
& +e_{i}=\hat{E} D_{i}+e_{D i} \\
S_{D i}=\hat{\beta}_{0}+\hat{\beta}_{1} E_{D i}+ & \hat{\beta}_{2} E_{D(t-1) i}+\hat{\beta}_{3} E n v_{D t i}+\hat{\beta}_{4} E n v_{D(t-1) i}+\hat{\beta}_{5} F_{C i}+\hat{\beta}_{6} F_{C(t-1) i}+\hat{\beta}_{7} S_{D(t-1) i} \\
& +e_{i}=\hat{S}_{D i}+e_{S i} \\
E n v=\hat{\beta}_{0}+\hat{\beta}_{1} E_{D i} & +\hat{\beta}_{2} E_{D(t-1) i}+\hat{\beta}_{3} S_{D t i}+\hat{\beta}_{4} S_{D(t-1) i}+\hat{\beta}_{5} F_{C i}+\hat{\beta}_{6} F_{C(t-1) i}+\hat{\beta}_{7} E_{n v_{D(t-1) i}} \\
& +e_{i}=E n v D_{i}+e_{E n v i}
\end{aligned}
$$


The OLS procedure minimizes the sum of squared residuals (Raykov \& Marcoulides, 2013):

$$
\begin{gathered}
s\left(\hat{\beta}_{0}, \ldots, \hat{\beta}_{7}\right)=\sum_{i=1}^{n} e_{i}^{2}=\sum_{i=1}^{n}\left(E_{D i}-\hat{E} D_{i}\right)^{2} \\
=\sum_{i=1}^{n}\left(y_{i}-\hat{\beta}_{0}-\hat{\beta}_{1} S_{D i}-\hat{\beta}_{2} S_{D(t-1) i}-\hat{\beta}_{3} E n v_{D t i}-\hat{\beta}_{4} E n v_{D(t-1) i}-\hat{\beta}_{5} F_{C i}\right. \\
\left.\quad-\hat{\beta}_{6} F_{C(t-1) i}-\hat{\beta}_{7} E_{D(t-1) i}\right)^{2} \rightarrow \min \\
s\left(\hat{\beta}_{0}, \ldots, \hat{\beta}_{7}\right)=\sum_{i=1}^{n} e_{i}^{2}=\sum_{i=1}^{n}\left(S_{D i}-\hat{S}_{D i}\right)^{2} \\
=\sum_{i=1}^{n}\left(y_{i}-\hat{\beta}_{0}-\hat{\beta}_{1} E_{D i}-\hat{\beta}_{2} E_{D(t-1) i}-\hat{\beta}_{3} E n v_{D t i}-\hat{\beta}_{4} E n v_{D(t-1) i}-\hat{\beta}_{5} F_{C i}\right. \\
\left.\quad-\hat{\hat{\beta}}_{6} F_{C(t-1) i}-\hat{\beta}_{7} S_{D(t-1) i}\right)^{2} \rightarrow \min \\
s\left(\hat{\beta}_{0}, \ldots, \hat{\beta}_{7}\right)=\sum_{i=1}^{n} e_{i}^{2}=\sum_{i=1}^{n}\left(E n v_{D i}-\widehat{E n v}_{D i}\right)^{2} \\
\quad=\sum_{i=1}^{n}\left(y_{i}-\hat{\beta}_{0}-\hat{\beta}_{1} E_{D i}-\hat{\beta}_{2} E_{D(t-1) i}-\hat{\beta}_{3} S_{D t i}-\hat{\beta}_{4} S_{D(t-1) i}-\hat{\beta}_{5} F_{C i}\right. \\
\left.\quad-\hat{\beta}_{6} F_{C(t-1) i}-\hat{\beta}_{7} E n v_{D(t-1) i}\right)^{2} \rightarrow \min
\end{gathered}
$$

In the last stage of the study, the results are presented, together with a discussion and final conclusions.

\section{Results of the research}

The indicators of economic $\left(\mathrm{E}_{\mathrm{D}}\right)$, social $\left(\mathrm{S}_{\mathrm{D}}\right)$, environmental $\left(\mathrm{Env}_{\mathrm{D}}\right)$, sustainable $(\mathrm{SI})$ development and the indicator of the financial condition $\left(\mathrm{F}_{\mathrm{C}}\right)$ of transport enterprises in 2008-2019 are presented in Table 2. The economic development indicator $\left(\mathrm{E}_{\mathrm{D}}\right)$

Table 2. Indicators of economic $\left(\mathrm{E}_{\mathrm{D}}\right)$, social $\left(\mathrm{S}_{\mathrm{D}}\right)$ and environmental $\left(\mathrm{Env}_{\mathrm{D}}\right)$, sustainable development $(\mathrm{Si})$ and the financial condition indicator $\left(\mathrm{F}_{\mathrm{C}}\right)$

\begin{tabular}{|l|c|c|c|c|c|c|c|c|c|c|c|c|}
\hline Indicator & 2008 & 2009 & 2010 & 2011 & 2012 & 2013 & 2014 & 2015 & 2016 & 2017 & 2018 & 2019 \\
\hline $\mathrm{E}_{\mathrm{D}}$ & 0.43 & 0.01 & 0.21 & 0.44 & 0.41 & 0.44 & 0.63 & 0.75 & 0.66 & 0.86 & 0.87 & 0.88 \\
\hline $\mathrm{S}_{\mathrm{D}}$ & 0.43 & 0.11 & 0.38 & 0.49 & 0.49 & 0.46 & 0.62 & 0.7 & 0.67 & 0.83 & 0.84 & 0.89 \\
\hline Env $_{\mathrm{D}}$ & 0.51 & 0.68 & 0.44 & 0.61 & 0.74 & 0.87 & 0.95 & 0.86 & 0.61 & 0.23 & 0.25 & 0.24 \\
\hline $\mathrm{SI}_{\mathrm{D}}$ & 0.46 & 0.27 & 0.34 & 0.51 & 0.55 & 0.59 & 0.73 & 0.77 & 0.65 & 0.64 & 0.65 & 0.67 \\
\hline $\mathrm{F}_{\mathrm{C}}$ & 0.35 & 0.41 & 0.63 & 0.60 & 0.61 & 0.60 & 0.58 & 0.65 & 0.52 & 0.47 & 0.45 & 0.56 \\
\hline
\end{tabular}

Source: own calculation based on (GUS, n.d.). 
increased from 0.43 in 2008 to 0.88 in 2019 . The social indicator $\left(\mathrm{S}_{\mathrm{D}}\right)$ increased from 0.43 in 2018 to 0.89 . On the other hand, the environmental development indicator $\left(\right.$ Env $\left._{\mathrm{D}}\right)$ decreased from 0.51 to 0.24 , while the financial condition of enterprises improved. The indicator increased from 0.35 in 2008 to 0.56 in 2019.

Table 3 presents selected descriptive statistics for the designated indicators. The highest average value $(0.58)$ is for social and environmental development indicators and the lowest for the financial condition (0.54). The highest level of the median occurred in the case of the sustainable development index (0.62). The highest maximum value was achieved by the ecological development index (0.95), the lowest by economic development (0.01).

Table 3. Descriptive statistics of economic $\left(E_{D}\right)$, social $\left(S_{D}\right)$ and environmental $\left(\operatorname{Env}_{D}\right)$, sustainable development $(\mathrm{SI})$ and the financial condition indicator $\left(\mathrm{F}_{\mathrm{C}}\right)$

\begin{tabular}{|l|c|c|c|c|c|l|c|}
\hline Indicator & Mean & Mediana & $\mathrm{SD}$ & Max & Min & Trend line & $\mathrm{R}^{2}$ \\
\hline $\mathrm{E}_{\mathrm{D}}$ & 0.55 & 0.54 & 0.26 & 0.88 & 0.01 & $\mathrm{E}_{\mathrm{D}}=0.0684 \mathrm{x}+0.1048$ & 0.80 \\
\hline $\mathrm{S}_{\mathrm{D}}$ & 0.58 & 0.56 & 0.22 & 0.89 & 0.11 & $\mathrm{~S}_{\mathrm{D}}=0.0576 \mathrm{x}+0.2015$ & 0.84 \\
\hline Env $_{\mathrm{D}}$ & 0.58 & 0.61 & 0.24 & 0.95 & 0.23 & $\mathrm{Env}_{\mathrm{D}}=-0.0275 \mathrm{x}+0.7614$ & 0.15 \\
\hline $\mathrm{SI}$ & 0.57 & 0.62 & 0.15 & 0.77 & 0.27 & $\mathrm{SI}_{\mathrm{D}}=0.0326 \mathrm{x}+0.3571$ & 0.60 \\
\hline $\mathrm{F}_{\mathrm{C}}$ & 0.54 & 0.57 & 0.09 & 0.65 & 0.35 & $\mathrm{~F}_{\mathrm{C}}=0.0044 \mathrm{x}+0.5074$ & 0.03 \\
\hline
\end{tabular}

Source: own calculation based on (GUS, n.d.).

The economic, social, sustainable development and financial condition of transport enterprises increased in the analysed period. The highest upward trend is in the economic development indicator (0.0684). The environmental development indicator has a negative slope $(-0.0275)$.

The Pearson correlation coefficients are shown in Table 4. The highest level of statistically significant dependence is between economic $\left(\mathrm{E}_{\mathrm{D}}\right)$ and social development $\left(\mathrm{S}_{\mathrm{D}}\right)(0.9865)$. There is a negative correlation between environmental development and economic $(-0.3818)$ and social development $(-0.4555)$. The highest level of dependence in the case of financial condition occurs in regard of environmental development (0.4254).

Table 4. The Pearson Correlation Coefficients, critical value (with two-sided $5 \%$ critical area) $=0.5760$ for $n=12$

\begin{tabular}{|c|c|c|c|c|}
\hline $\mathrm{E}_{\mathrm{D}}$ & $\mathrm{S}_{\mathrm{D}}$ & $\operatorname{Env}_{\mathrm{D}}$ & $\mathrm{F}_{\mathrm{C}}$ & \\
\hline 1.0000 & 0.9865 & -0.3818 & 0.0542 & $\mathrm{E}_{\mathrm{D}}$ \\
\hline & 1.0000 & -0.4555 & 0.1193 & $\mathbf{S}_{\mathbf{D}}$ \\
\hline & & 1.0000 & 0.4254 & $\mathbf{E n v}_{\mathbf{D}}$ \\
\hline & & & 1.0000 & $\mathbf{F}_{\mathbf{C}}$ \\
\hline
\end{tabular}

Source: own calculation based on (GUS, n.d.). 
Table 5 presents the results of the SUR estimation. The multi-equation model consists of three equations, where the dependent variables are the indicators of economic $\left(\mathrm{E}_{\mathrm{D}}\right)$, social $\left(\mathrm{S}_{\mathrm{D}}\right)$ and environmental development $\left(\right.$ Env $\left._{\mathrm{D}}\right)$. The explanatory variables include the relationships between the dependent variables from period $t$ and period $(t-1)$ and the impact of the exogenous variable financial condition $\left(\mathrm{F}_{\mathrm{C}}\right)$.

Table 5. The OLS estimation, explained variables: indicators of economic $\left(\mathrm{E}_{\mathrm{D}}\right)$, social $\left(\mathrm{S}_{\mathrm{D}}\right)$ and environmental $\left(\right.$ Env $\left._{\mathrm{D}}\right)$ development

\begin{tabular}{|c|c|c|c|c|c|c|}
\hline $\begin{array}{c}\text { Dependent } \\
\text { variable }\end{array}$ & $\begin{array}{c}\text { Explanatory } \\
\text { variable }\end{array}$ & Coefficient & SD & $t$-Student & $p$-value & $\mathrm{R}^{2}$ \\
\hline \multirow[t]{8}{*}{$E_{D}$} & const & -0.181995 & 0.0518735 & -3.508 & 0.0392 & \multirow{8}{*}{0.999} \\
\hline & $S_{D}$ & 1.27991 & 0.0551674 & 23.20 & 0.0002 & \\
\hline & $S_{D(t-1)}$ & 1.28855 & 0.280905 & 4.587 & 0.0195 & \\
\hline & $\operatorname{Env}_{D}$ & 0.186841 & 0.0404203 & 4.622 & 0.0191 & \\
\hline & $\operatorname{Env}_{D(t-1)}$ & 0.168587 & 0.0488185 & 3.453 & 0.0408 & \\
\hline & $\mathrm{F}_{\mathrm{C}}$ & -0.433680 & 0.100395 & -4.320 & 0.0229 & \\
\hline & $\mathrm{F}_{\mathrm{C}(\mathrm{t}-1)}$ & -0.366812 & 0.106063 & -3.458 & 0.0407 & \\
\hline & $E_{D(t-1)}$ & -0.954476 & 0.209343 & -4.559 & 0.0198 & \\
\hline \multirow[t]{8}{*}{$S_{D}$} & const & 0.138285 & 0.0442890 & 3.122 & 0.0524 & \multirow{8}{*}{0.999} \\
\hline & $E_{D}$ & 0.776974 & 0.0334896 & 23.20 & 0.0002 & \\
\hline & $E_{D(t-1)}$ & 0.740639 & 0.167636 & 4.418 & 0.0215 & \\
\hline & $\operatorname{Env}_{D}$ & -0.148353 & 0.0268252 & -5.530 & 0.0116 & \\
\hline & $\operatorname{Env}_{D(t-1)}$ & -0.129444 & 0.0401579 & -3.223 & 0.0485 & \\
\hline & $\mathrm{F}_{\mathrm{C}}$ & 0.343443 & 0.0697045 & 4.927 & 0.0160 & \\
\hline & $\mathrm{F}_{\mathrm{C}(\mathrm{t}-1)}$ & 0.287041 & 0.0811880 & 3.536 & 0.0385 & \\
\hline & $S_{D(t-1)}$ & -0.995431 & 0.231484 & -4.300 & 0.0231 & \\
\hline \multirow[t]{4}{*}{$\operatorname{Env}_{D}$} & const & 0.399759 & 0.289620 & 1.380 & 0.2100 & \multirow{4}{*}{0.867} \\
\hline & $\mathrm{E}_{\mathrm{D}}$ & 3.99902 & 0.861706 & 4.641 & 0.0024 & \\
\hline & $\mathrm{S}_{\mathrm{D}}$ & -5.40087 & 1.05745 & -5.107 & 0.0014 & \\
\hline & $\mathrm{F}_{\mathrm{C}}$ & 2.04740 & 0.478631 & 4.278 & 0.0037 & \\
\hline
\end{tabular}

Source: own calculation based on (GUS, n.d.).

The results of the OLS method indicate the diversification of the influence of the dependent variables on the dependent variable. The economic development $\left(\mathrm{E}_{\mathrm{D}}\right)$ depends on social development $\left(\mathrm{S}_{\mathrm{D}}\right)$, social development from the period $(t-1)$ $\left(\mathrm{S}_{\mathrm{D}(\mathrm{t}-1)}\right)$, environmental development $\left(\mathrm{ENV}_{\mathrm{D}}\right)$, environmental development from the 
period $(t-1)\left(\operatorname{Env}_{\mathrm{D}(t-1)}\right)$, financial condition from the period $t\left(\mathrm{~F}_{\mathrm{C}}\right)$ and period $(t-1)\left(\mathrm{F}_{\mathrm{C}(\mathrm{t}-1)}\right)$ and the economic development indicator from the period $(t-1)\left(\mathrm{E}_{\mathrm{D}(t-1)}\right)$. It is worth noting the negative sign with the variable financial condition, as this means that the financial condition $\left(\mathrm{F}_{\mathrm{C}}\right)$ improvement causes a decrease in the economic development indicator $\left(\mathrm{E}_{\mathrm{D}}\right)$.

The social indicator depends $\left(\mathrm{S}_{\mathrm{D}}\right)$ on the economic development indicator from period $t\left(\mathrm{E}_{\mathrm{D}}\right)$ and period $(t-1)\left(\mathrm{E}_{\mathrm{D}(t-1)}\right)$, environmental development indicator from period $t\left(\operatorname{Env}_{\mathrm{D}}\right)$ and period $(t-1)\left(\mathrm{Env}_{\mathrm{D}(\mathrm{t}-1)}\right)$, financial condition from period $t\left(\mathrm{~F}_{\mathrm{C}}\right)$ and period $(t-1)\left(\mathrm{F}_{\mathrm{C}(\mathrm{t}-1)}\right)$ and social development from the period $(t-1)\left(\mathrm{S}_{\mathrm{D}(\mathrm{t}-1)}\right)$. The signs of the coefficients indicate that economic development $\left(\mathrm{E}_{\mathrm{D}}\right)$ and financial condition $\left(\mathrm{F}_{\mathrm{C}}\right)$ have a positive effect on social development $\left(\mathrm{S}_{\mathrm{D}}\right)$. The negative sign is in the case of environmental development $\left(\right.$ Env $\left._{\mathrm{D}}\right)$ (an increase in the environmental development indicator causes a decrease in the social indicator) and social development from the period $(t-1)\left(\mathrm{S}_{\mathrm{D}(\mathrm{t}-1)}\right)$. The justification here may be the fact that the financial resources concentrate on environmental, and not on social investments. Moreover, the implementation of social investments in the previous period may limit the development of current social development investments (lack of financial resources).

The environmental indicator $\left(\operatorname{Env}_{\mathrm{D}}\right)$, in turn, depends on economic development $\left(\mathrm{E}_{\mathrm{D}}\right)$ (economic growth causes an increase in the environmental development indicator), social development $\left(\mathrm{S}_{\mathrm{D}}\right)$ (negative correlation) and financial condition $\left(\mathrm{F}_{\mathrm{C}}\right)$ (a good financial condition enables investment in environmental protection).

\section{Conclusion}

Sustainable development is a response to climate change and the depletion of natural resources. Its primary goal is to preserve the present state of nature for future generations. Sustainable development includes three pillars: economic, social, and environmental, and requires action at the macroeconomic (requires international institutions and states) and microeconomic (enterprises, households) levels.

The sustainable development of an enterprise means taking actions to maximize profit while carrying out social tasks and protecting the natural environment. In business practice, this means implementing ecological investments and developing employees, knowledge, and skills. Economic, social, and environmental development are closely related, however it should be emphasized that some researchers indicate that economic development is the basis for sustainable development. Economic development enables further actions to be taken for the benefit of society and the environment, and is a derivative of the company's financial and property situation.

The research results indicate that the pillars of the sustainable development of transport enterprises are closely interrelated and depend on the financial condition of enterprises. The central research hypothesis $(\mathrm{H})$ is correct because "the financial 
condition had a statistically significant impact on the economic $\left(\mathrm{E}_{\mathrm{D}}\right)$, social $\left(\mathrm{S}_{\mathrm{D}}\right)$ and environmental development ( $\left.\operatorname{Env}_{\mathrm{D}}\right)$ of transport enterprises in Poland in 2008-2019".

The first sub-hypothesis is not correct as the positive trend is for the economic (0.0684) and social indicator (0.0576), and the negative trend is for the ecological indicator (-0.0275). The second sub-hypothesis is correct because from 2008 to 2019, the financial condition of transport enterprises in Poland improved (0.0044). The third sub-hypothesis is also correct because economic development was statistically essential for the social and environmental development of transport enterprises in Poland in 2008-2019.

The OLS estimation results show strong dependencies between sustainable development pillars and indicate a statistically significant sign of the financial condition for economic, social, and environmental development.

Therefore, enterprises implementing sustainable development strategies should secure their financial and property standing, which is the starting point for ecological and social investments. Undoubtedly, their favourable financial situation makes it possible to obtain preferential loans for financing sustainable development goals.

\section{References}

Adamczyk, J. (2001). Koncepcja zrównoważonego rozwoju w zarządzaniu przedsiębiorstwem. Zeszyty Naukowe. Akademia Ekonomiczna w Krakowie, Seria Specjalna, Monografie, 145(258).

Adamkiewicz-Drwiłło, H. G., \& Kruk, H. (2010). Zrównoważona konkurencyjność przedsiębiorstw ujęcie teoretyczne. Studia i Prace Kolegium Zarzq̨zania i Finansów, (98), 16-24.

Ahlgren, P., Jarneving, B., \& Rousseau, R. (2003). Requirements for a co-citation similarity measure, with special reference to Pearson's correlation coefficient. Journal of the American Society for Information Science and Technology, 54(6).

Behringer, K., \& Szegedi, K. (2016). The role of CSR in achieving sustainable development - theoretical approach. European Scientific Journal. ESJ, 12(22), 10.

Bembenek, B. (2015, February). The sustainable development of an industrial cluster in the context of corporate social responsibility - a new challenge for cluster management. European Scientific Journal.

Carroll, A. B. (2015). Corporate social responsibility. The centrepiece of competing and complementary frameworks. Organizational Dynamics, 44, 87-96.

Comporek, M., Kowalska, M., \& Misztal, A. (2021). The sustainable development of transport enterprises in the context of macroeconomic conditions. The case of Central and Eastern European Countries. Entrepreneurship and Sustainability Issues, (8), 3.

Czyż, M. (2000). Rozwój zrównoważony a przemiany cywilizacyjne. In S. Zięba, \& M. Wróblewski (Eds.), Ekologia a transformacje cywilizacyjne na przełomie wieków. Lublin: UMCS.

Drljača, M. (2012). Koncept održivograzvoja i sustavupravljanja. Međunarodni skup nedeljakvaliteta. Kvalitet i Izvrsnos, 1(1-2), 1-15.

Ernst, A., \& Albers, C. (2017). Regression assumptions in clinical psychology research practice. A systematic review of common misconceptions. PeerJ 5, e3323. Retrieved January 10, 2020 from https://peerjcom/articles/3323pdf

Firlej, K. (2005). Rola i miejsce zrównoważonego rozwoju w działalności polskich przedsiębiorstw. Integracja problemów środowiskowych i teorii zrównoważonego rozwoju w systemie zarzadzania 
przedsiębiorstwem. Białystok: Politechnika Białostocka, Centrum Zrównoważonego Rozwoju i Zarządzania Środowiskiem.

Giovannoni, E., \& Fabietti, G. (2013). What is sustainability? A review of the concept and its applications. In C. Busco, M. L. Frigo, P. Quattrone, \& A. Riccaboni (Eds.), Integrated reporting. Concepts and cases that redefine corporate accountability. Berlin: Springer.

Gorczyńska, M. (2013). Stabilność finansowa a zrównoważony rozwój przedsiębiorstwa. Zarzqdzanie $i$ Finanse, 2(2), 99-110.

GUS. (n.d.). Retrieved January 4, 2021 from stat.gov.pl

Ikram, M., Zhou, P., Shah, S. A. A., \& Liu, G. Q. (2019). Do environmental management systems help improve corporate sustainable development? Evidence from manufacturing companies in Pakistan. Journal of Cleaner Production, 226, 628-641.

Janas, M. (2019). Konkurencyjność i innowacyjność przedsiębiorstw sektora MŚP w Polsce. Prace Komisji Geografii Przemystu Polskiego Towarzystwa Geograficznego, 33(4), 176-194.

Johnson, O., Sunday, S., Chimkwanum, O., \& Samesa, I. (2020). Exploring the pillars of sustainable development in the context of Ghanaian SMEs. Journal of Economics and Sustainable Development, 10(14), 26-34.

Kang, S., \& Na, Y. K. (2020). Effects of strategy characteristics for sustainable competitive advantage in sharing economy businesses on creating shared value and performance. Sustainability, 12, 1397.

Kapecki, T. (2020). Elements of sustainable development in the context of the environmental and financial crisis and the covid-19 pandemic. Sustainability, 12, 6188.

Karagülle, A. (2012). Green business for sustainable development and competitiveness: An overview of the Turkish logistics industry. Procedia. Social and Behavioral Sciences, 41, 456-460.

Kokić, A., Mišić, M., Radojković, M., \& Prlinčević, B. (2016). Social aspects of sustainable development of enterprises (1st International conference on Quality of Life, June 2016). Retrieved from http://cqm.rs/2016/cd1/pdf/papers/focus_1/11.pdf

Koszel, M., \& Weinert, A. (2013). Wykorzystanie koncepcji społecznej odpowiedzialności przedsiębiorstw i zrównoważonego rozwoju w kreowaniu innowacyjnego produktu - studia przypadków. Zeszyty Naukowe Uniwersytetu Szczecińskiego. Studia i Prace Wydziału Nauk Ekonomicznych i Zarzqdzania, 2(32).

Lagoarde-Segot, T. (2020). Financing the sustainable development goals. Sustainability, 12, 2775.

Leśniewski, M. (2017). The eco-developmental organisational culture in the eco-developmental competitiveness of business enterprises. Jagiellonian Journal of Management, 3(1), 17-34.

Mao, J., Li, C., Pei, Y., \& Xu, L. (2018). Circular economy and sustainable development enterprises. Singapore: Springer.

Masztalerz, M. (2019). Raportowanie wskaźników finansowych przez spółki publiczne. Zeszyty Teoretyczne Rachunkowości, 103(159), 99-118.

McIntyre, J. R., Ivanaj, S., \& Ivanaj, V. (2009). Multinational enterprises and the challenge of sustainable development. Cheltenham-Northampton: Edward Elgar Publishing Limited.

Misztal, A. (2019). Stabilizacja makroekonomiczna a zrównoważony rozwój przedsiębiorstw - przypadek Bułgarii. Czech. Polski i Rumunii. Studia Prawno Ekonomiczne, 113, 189-205.

Misztal, A., \& Kowalska, M. (2020). Determinants of sustainable development of industrial enterprises in Poland in the period from 2010 to 2019 - a statistical evaluation. Prace Naukowe Uniwersytetu Ekonomicznego we Wroclawiu, 64, 160-173.

Moya-Clemente, I., Ribes-Giner, G., \& Pantoja-Díaz, O. (2020). Identifying environmental and economic development factors in sustainable entrepreneurship over time by partial least squares (PLS). PLoS ONE, 15(9), e0238462.

Osmanagić Bedenik, N. (2018). Business between profitability and sustainability. EFZG Working Papers Series, 18(03). 
Oželienė, D. (2017). A review of enterprise sustainable development models: Critical appraisal, scientific proceedings (International scientific conference "High technologies. Business. Society"). Retrieved from https://hightechsociety.eu/sbornik/2017/2/26.A\%2520REVIEW\%2520OF\% 2520ENTERP RISE\%2520SUSTAINABLE\%2520DEVELOPMENT\%2520MODELS\%2520CR ITICAL\%2520A PPRAISAL.pdf

Pieloch-Babiarz, A., Misztal, A., \& Kowalska, M. (2020). The impact of macroeconomic stabilization on the sustainable development of manufacturing enterprises: The case of Central and Eastern European Countries. Environ Dev Sustain.

Piontek, B. (2002). Koncepcja rozwoju zrównoważonego i trwałego Polski. Warszawa: Wydawnictwo Naukowe PWN.

Porter, M. E. \& Kramer, M. R. (2007). Strategy and society. the link between competitive advantage and corporate social responsibility. Harvard Business Review, 84(12), 78-92.

Raykov, T., \& Marcoulides, G. A. (2013). Basic statistics: An introduction with R. Lanham, MD: Rowman \& Littlefield Publishers.

Ricart, J., Rodríguez, M., \& Sánchez, P. (2002). Sustainable development and the sustainability of competitive advantage: A dynamic and sustainable view of the firm. Creativity and Innovation Management, 11 .

Sarkar, A. N. (2013). Promoting eco-innovations to leverage sustainable development of eco-industry and green growth. Eur. J. Sustain. Dev., 2, 171-224.

Schroeder, D. M., \& Robinson, A. G. (2010). Green is free: Creating sustainable competitive advantage through green excellence, Organizational Dynamics, 39, 345-352.

Seelos, Ch., \& Mair, J. (2005). Sustainable development. Sustainable profit. European Business Forum. 49-53.

Skoczylas, W., \& Waśniewski, P. (2014). Wskaźniki finansowe w raporcie z badania sprawozdania finansowego przez biegłego rewidenta. Zeszyty Naukowe Uniwersytetu Szczecińskiego. Finanse. Rynki Finansowe. Ubezpieczenia, 69, 243-252.

Srivastava, M., Franklin, A., \& Martinette, L. (2013). Building a sustainable competitive advantage. Journal of Technology Management \& Innovation, 8, 47-60.

Szanduła, J. (2014). Uwagi do unitaryzacji zmiennych w referencyjnym systemie granicznym. Przeglad Statystyczny, 2.

Takeshi, A. (1985). Advanced Econometrics, Cambridge. Massachusetts: Harvard University Press.

Trojanowski, T. (2015). Przedsiębiorstwo wobec wyzwań zrównoważonego rozwoju. Zeszyty Naukowe Politechniki Ślaskiej, Organizacja i Zarzqdzanie, 77.

Witek-Crabb, A. (2005). Zrównoważony rozwój przedsiębiorstw - więcej niż ekorozwój. In H. Brdulak, \& T. Gołębiowski (Eds.), Trans'05 Wspólna Europa. Zrównoważony rozwój przedsiębiorstwa a relacje z interesariuszami. Warszawa: Szkoła Główna Handlowa w Warszawie.

Yeasmin, N. (2016). The determinants of sustainable entrepreneurship of immigrants in Lapland: An analysis of theoretical factors. Entrepreneurial Business and Economics Review, 4(1), 129-159.

Yemelyanov, O., Petrushka, T., Symak, A., Trevoho, O. M., Turylo, A., Kurylo, O., Danchak, L., Symak, D., \& Lesyk, L. (2020). Microcredits for sustainable development of small Ukrainian enterprises: Efficiency, accessibility, and government contribution. Sustainability, 12, 6184.

Yurdakul, M., \& Kazan, H. (2020). Effects of eco-innovation on economic and environmental performance: Evidence from Turkey's manufacturing companies. Sustainability, 12, 3167. 


\section{OCENA WPLYWU KONDYCJI FINANSOWEJ NA KOMPONENTY ZRÓWNOWAŻONEGO ROZWOJU PRZEDSIĘBIORSTW TRANSPORTOWYCH W POLSCE W LATACH 2008-2019}

Streszczenie: Zrównoważony rozwój przedsiębiorstwa obejmuje osiaganie celów ekonomicznych, społecznych i środowiskowych. W praktyce biznesowej oznacza on podejmowanie działań na rzecz maksymalizacji zysków przy jednoczesnej realizacji zadań społecznych i ekologicznych. Podstawowym celem artykułu jest ocena wpływu kondycji finansowej na komponenty zrównoważonego rozwoju przedsiębiorstw transportowych w Polsce w latach 2008-2019. Podstawową metodą wykorzystaną w opracowaniu jest podwójna metoda najmniejszych kwadratów, umożliwiająca oszacowanie trzech równań, w których zmiennymi endogenicznymi są rozwój ekonomiczny $\left(\mathrm{E}_{\mathrm{D}}\right)$, społeczny $\left(\mathrm{S}_{\mathrm{D}}\right)$ i środowiskowy $\left(\right.$ Env $\left._{\mathrm{D}}\right)$. Zgodnie z wynikami estymacji poszczególne komponenty są od siebie uzależnione. Kondycja finansowa $\left(\mathrm{F}_{\mathrm{C}}\right)$ z okresu bieżącego i poprzedniego ma wpływ na rozwój ekonomiczny i społeczny, rozwój środowiskowy zaś jest uzależniony od kondycji finansowej w bieżącym okresie.

Słowa kluczowe: kondycja finansowa, zrównoważony rozwój, przedsiębiorstwa transportowe, klasyczna metoda najmniejszych kwadratów. 